\title{
JARDINES DE PAPEL: LA TEORÍA Y LA TRATADÍSTICA DEL JARDÍN EN ESPAÑA DURANTE EL SIGLO XIX
}

\author{
Eva J. Rodríguez Romero \\ Arquitecto - Depto. de Historia del Arte. Centro de Estudios Históricos. CSIC \\ Duque de Medinaceli, 6 - 28014 Madrid (España)
}

\section{RESUMEN}

Se estudia el panorama que, a nivel teórico, presentaba la jardinería en España durante el siglo XIX. Tras un breve recorrido por la teoría española del jardín desde el Renacimiento, comenzamos por rastrear las referencias en libros de viaje, tratados de arquitectura y publicaciones periódicas que completaban la tratadística específica, para abordar a continuación el análisis de los estudios sobre el jardín en obras de teoría y tratados de jardinería, así como en libros de agricultura y botánica publicados en España a lo largo del siglo XIX. Predominaban los tratados prácticos, de índole agrícola o botánica aplicados a la jardinería, sobre las obras de teoría del jardín propiamente dichas; además, estas últimas eran deudoras de los tratados y libros de imágenes que nos llegaban desde el extranjero.

\section{SUMMARY}

The theoretic panorama of spanish gardening in nineteen ${ }^{\text {th }}$ century is studied. After covering a spanish garden theory abstract since the Renaissance, the studies of the garden are analyzed in the publicated and no publicated books of gardening theory, agriculture and botany in Spain throughout all this century. The agricultural and botanical practical treatise predominated over specific gardening treatise which were indebted to foreigner treatise. These publications were completed by several references in travel books, architectural essaies and papers.

«Yacía aquí (la jardinería) abandonada, mientras que en los países más civilizados de Europa hacían de este arte por si solo una profesión, que se enseñaba por verdaderos principios, para formar lo que hoy se llaman arquitectos de jardín.» En España se practica el género paisajista con «una instintiva e imperfecta imitación; en ninguna cátedra o escuela se explica ni se da a conocer por sus verdaderos principios» ${ }^{1}$. Con este desalentador panorama se refiere Fernández de los Ríos a la jardinería española

\footnotetext{
1 FERNÁNdez de Los Ríos, A. (1876), Guía de Madrid, pp. 326-327.
} 
de su siglo. Efectivamente, como también apuntaban otros estudiosos de la época ${ }^{2}$, en España no se prestaba tanta atención a la jardinería como en otros países, tanto en el ámbito de la formación de profesionales, como en el ámbito práctico de las realizaciones de jardines en concreto.

Por supuesto, nuestros jardines paisajistas no surgieron de la nada; las influencias inglesas y francesas, sobre todo, llegaron a partir de la segunda mitad del siglo XVIII, de forma indirecta a través de los libros de viaje y de la literatura ${ }^{3} \mathrm{y}$, directamente, mediante la bibliografía extranjera que era importada por la realeza, la nobleza y las personas ilustradas ${ }^{4}$. Asimismo, debemos recordar que la mayoría de los jardineros importantes que están trabajando desde comienzos del siglo XVIII y durante casi todo el siglo XIX son franceses principalmente, o italianos, siendo ellos mismos uno de los vehículos de difusión del paisajismo en nuestro país. Además, al contrario que en Inglaterra y Francia, por ejemplo, aquí se construyeron las mejores realizaciones de este estilo antes de que apareciese el primer tratado sobre el tema, el cual no se publica hasta la década de los cuarenta, aunque sí habían sido traducidos algunos tratados específicos ya a comienzos del siglo XIX.

Lógicamente, nuestro corpus teórico sobre el jardín paisajista no alcanzó la importancia, originalidad, extensión y difusión de las tratadísticas inglesa o francesa, pero eso no quiere decir que no existan obras de teoría del jardín en España durante el siglo XIX y tampoco supone una total ausencia de formación de los profesionales españoles. Estos escritos y tratados españoles, tan poco estudiados hasta el momento, merecen ser analizados para poder calibrar su verdadera incidencia en la jardinería de la época, siendo éste el objetivo que abordamos.

\section{LA TEORÍA DEL JARDÍN EN ESPAÑA. ANTECEDENTES.}

Mariano Rodríguez de Rivas, en su crónica sobre la exposición La jardinería romántica española, se queja de lo poco estudiada que está la filosofía romántica del jardín español y denuncia la «maltratada historiografía de nuestros jardines» ${ }^{5}$ si la

2 Mesonero Romanos, R. de (1844), Manual histórico-topográfico y artístico de Madrid, p. 403, pone de manifiesto la poca afición de los madrileños a los jardines, siendo «bastante rara esta comodidad y desahogo» y MADOZ, P. (1847), Diccionario geográfico-estadístico-histórico de España..., tomo X, p. 902, corrobora que Madrid era un «pueblo poco aficionado, hasta hace algún tiempo, a esta clase de recreo» .

${ }^{3}$ Cfr. Sото CABA, V. (1993), «El jardín romántico en la España ilustrada: una visión en la literatura», Espacio, tiempo y forma, serie VII, 6, 407-432.

${ }_{4}$ Cfr. RODRíGUEZ ROMERO, E. (1997), «El jardín paisajista y la mujer en España: la Alameda de Osuna, el Casino de la Reina y Vista Alegre», La mujer en el arte español, VIII Jornadas de Arte, Dpto. de Historia del Arte, C.S.I.C., 347-366.

5 RODRÍGUEZ DE RIVAS, M. (1955), «En torno a la jardinería romántica española», Cedro, 5, 5-9, p. 6. Se trata de una crónica de la exposición realizada en el Museo Romántico de Madrid en 1954, donde se 
comparamos con la sugestiva y personal «teoría romántica sobre los jardines» en Europa, que supone un nuevo arte jardinero repleto de premisas y con una «legión de los técnicos más estudiosos que se aplican a inventar un estilo», aunque luego el jardín aparezca «con ese dulce abandono, como hijo de nadie, surgido de la nada ${ }^{6}$. De hecho, este autor no señala ninguna referencia bibliográfica española que sea realmente un tratado de teoría del jardín, pues los escritos a los que hace referencia son más bien tratados de agricultura o como mucho de jardinería práctica. Bien es verdad que esta literatura fue mucho más abundante durante el siglo pasado que la de teoría del jardín propiamente dicha. Así, es mucho más fácil encontrar manuales prácticos sobre el cultivo de plantas para el jardín o recetarios de diseño jardinero que libros que versen sobre la filosofía, la historia o el análisis morfológico del jardín paisajista estudiados en profundidad y con rigor teórico.

Pero este fenómeno es generalizable a otras épocas respecto de la teoría de jardines, que muchas veces ocupaba un espacio dentro de los tratados correspondientes a otras disciplinas, como la arquitectura, o incluso debía ser rastreada dentro de la literatura, en poemas, novelas, libros de viaje, etc., sin llegar a tener un corpus propio. Desde siempre, también la teoría del jardín y la teoría de la agricultura, e incluso algunos aspectos de la botánica, han compartido lugar o se han confundido. Es difícil hablar de una teoría del jardín antes del Renacimiento, aunque desde la Antigüedad existan innumerables tratados de agricultura, o libros sobre huertos o jardines medicinales, que precisamente en aquella época serían traducidos, retomados o reeditados, apareciendo los libros de villa, los re rustica, etc. que conjugan, entre otras cosas, agricultura y diseño del jardín. De la misma manera, dentro de la literatura de todos los tiempos pueden hallarse referencias más o menos explícitas al mundo de los jardines.

Fue en el siglo XVIII, con el irrumpimiento de la teoría sobre el jardín paisajista, cuando, por vez primera en la historia, el número de tratados teóricos sobre esta disciplina superó a las aportaciones originales dentro del campo de la práctica jardinera del cultivo vegetal. Poco después llegaron los manuales, los repertorios de láminas con imágenes y ejemplos a imitar... que extendieron rápidamente el gusto por el nuevo estilo de jardín, para que, otra vez, a finales del siglo XVIII y durante casi todo el siglo XIX, se volviese a poner el acento en el lado científico de la jardinería, en las composiciones vegetales y su estudio, con la moda de las especies exóticas, que perduraría todo el pasado siglo fundamentada en serios y numerosos escritos como los de Loudon.

Seguiremos de forma somera el rastro de la teoría de jardines en general y en España, en particular, hasta llegar a la centuria que nos ocupa. Como hemos indicado,

justifica la escasez de tratadística sobre el jardín romántico y también las pocas realizaciones en este estilo por el hecho de que nuestros jardineros se hallasen esterilizados ante la herencia extraordinaria de nuestros jardines históricos de siglos pasados, lo que les obligaba a la conservación más que a la revisión (p. 7).

6 RODRÍGUEZ DE RIVAS, M. (1955), p. 5. 
podemos considerar que la teoría del jardín nace durante el Renacimiento, retomando en gran medida la tradición clásica de los rustica scriptores. El punto de partida se situaría en una novela que generará todo el mundo renaciente de alusiones simbólicas como argumentos en el jardín, la Hypnerotomachia Poliphili (Venecia, 1499) de Francesco Colonna. Aparece también un nuevo género literario que es el «poema de jardín», donde se cantan las bellezas y beneficios de frondosos vergeles, jardines y huertos 7 . Podemos comprobar, pues, que efectivamente la teoría del jardín no ocupa aún su propio lugar, sino que permanece intrusa dentro del mundo literario.

Por otro lado estarían también los libros de historia natural, los de agricultura y botánica, como el conocido Dioscórides, los libros de agricultura árabes, los tratados renacentistas de arquitectura, e incluso los tapices de verdura y los libros de horas donde se pueden hallar recreaciones de jardines ideales. Hay que esperar al siglo XVI para encontrar el primer tratado sobre jardines, aunque es más un manual práctico donde se incluyen maneras de cultivar frutales y huertos medicinales que un libro de teoría. Nos referimos a la obra de Thomas Hill, A most brief and Pleasant Teatrise Teaching how to dress, sow and set a Garden (1563), que tendrá diecisiete reediciones más bajo el título de The Profitable Art of Gardening.

En España será muy importante la conocidísima obra de Gabriel Alonso de Herrera, Agricultura, escrita a comienzos del siglo XVI e inspirada en la jardinería islámica y apoyada en Columela y Palladius, el escritor rústico, pero sobre todo en la práctica de la agricultura y del regadío, que en la España del XVI es fundamentalmente de raíces islámicas ${ }^{8}$. Pero el primer tratado de jardinería escrito en castellano, y uno de los más importantes de Europa, será la Agricultura de Jardines (1592) de Gregorio de los Ríos 9 . Si bien existían ya muchas obras sobre plantas medicinales o plantas de interés agrícola, todavía no se había escrito un tratado de plantas ornamentales («agradables a la vista») que además incluyera todos los apartados típicos de una obra de este género: diseño del jardín, recomendaciones de siembra, plantación y mantenimiento, catálogo de árboles, arbustos, etc... Según Gregorio de los Ríos un jardinero debe «gobernar y mantener el jardín» previamente trazado, por lo que no incluye ideas sobre el diseño del jardín, pues para él es una actividad aparte, aunque sí se muestra partidario del jardín latino cuando describe algunas formalizaciones de jardín. Este manual de jardinería, aunque realmente sea más un tratado práctico que

\footnotetext{
7 Cfr. AÑón, C. (1991 a), «La literatura de jardines en el siglo XVI. Del Hortus al Jardín de Delicias», en FERNÁNDEZ PÉREZ, J. y GONZÁLEZ TASCÓN, I. eds.: A propósito de la Agricultura de Jardines de Gregorio de los Ríos, estudios y ed. fc., Tabapress, C.S.I.C. y Ayto. de Madrid, 81-102.

8 Sobre esta relación del jardín y la agricultura en la España del siglo XVI con la herencia del mundo del Islam, ver CHECA CREMADES, F. (1984), «El arte islámico y la imagen de la Naturaleza en la España del siglo XVI», Fragmentos, 1, 23-43.

9 Ver un análisis de este tratado en FERNÁNDEZ SANMARTín, A. et all. (1991), «Comentario a la Agricultura de Jardines», en FERNÁNDEZ, J. y GONZÁLEZ TASCÓN, I. eds.: A propósito de la Agricultura de Jardines..., 63-80.
} 


\section{LA TEORÍA Y LA TRATADÍSTICA DEL JARDÍN EN ESPAÑA DURANTE EL SIGLO XIX}

un libro de teoría propiamente dicho, es el primero de su clase en Europa, ya que se ocupa sólo de las plantas ornamentales y el propio autor resalta la diferencia de su obra respecto a otros escritos de agricultura ${ }^{10}$. Así, aquel jardín renacentista que se caracterizaba por su esquema de cuadros de origen medieval que Italia había enriquecido con juegos de agua y un cortejo de alegorías mitológicas, ve como las técnicas del jardín comienzan a hacer su tímida aparición en libros donde la jardinería empieza a desgajarse de la agricultura adquiriendo entidad propia.

El jardín español en el siglo XVI tiene una singular importancia, ya que sintetizaba diversas influencias que se pueden rastrear en las páginas de la literatura de la época, que es donde hay que buscar la teoría del jardín del Renacimiento español, ya que hemos visto que tan sólo existe un buen tratado y ni siquiera hay referencias teóricas al tema del jardín en los tratados de arquitectura ${ }^{11}$. Así, en los libros de viajes se puede apreciar, en las descripciones de jardines, la recepción de lo italiano, que en España se produce sobre un sustrato medieval cristiano más islámico, que conduce a una peculiaridad ecléctica del Renacimiento español donde se entremezclan elementos góticos, islámicos y clásicos. La influencia italiana del jardín de terrazas, con amplias perspectivas, donde se da una dialéctica naturaleza-artificio se encuentra también en la literatura y en la pintura. Por ejemplo, en el poema Laurentina de Luis Cabrera de Córdoba se describen los jardines de El Escorial y de Aranjuez. Por otro lado, las influencias de Flandes hacen que el jardín se inicie con formas geométricas y se acabe mucho menos formalizado, integrado con la naturaleza. Además están presentes lo maravilloso, la sorpresa... con multitud de animales, plantas, colores, fuentes de burlas, etc. En la visita de Lope de Vega al jardín de los Alba en Abadía a finales del siglo XVI, el jardín se presenta como paraíso, como un microcosmos o lugar que encierra en un pequeño espacio toda una imagen del Universo. También es frecuente encontrar una valoración de la casa de campo como lugar de retiro. Debemos recordar que esta idea de retiro tenía que ver con la mentalidad islámica y con la filosofía estoica. Ya en 1651 Pedro Soto de Rojas escribe el poema Paraíso cerrado para muchos, jardines abiertos para pocos que explica ese carácter de retiro, ese sentido elitista del jardín y lo liga a la filosofía estoica, a la idea de control de las pasiones.

En el siglo XVII aparece la enorme figura de Le Nôtre que conjuga un profundo conocimiento de botánica, de las técnicas de jardinería y su afición al dibujo y la

10 AÑón, C. (1991 b), «Nature et jardins dans 1'Espagne du XVIII ${ }^{\mathrm{e}}$ siècle», en MoSSER, M. y TEYSSOT, G. eds.: Histoire des jardins de la Renaissance à nos jours, Ed. Flammarion, Paris, 277-288, p. 281. Debemos resaltar también que el jardín ideal que plantea Gregorio de los Ríos en su tratado coincide con el jardín de la Casa de Campo, de donde él es capellán y jardinero, con su zona ornamental, su huerta, su jardín medicinal y su jardín de frutales. Se podían apreciar la influencia romana y la impronta árabe que daban como resultado un tipo de jardín específico donde el simbolismo de flores y plantas convertía el trabajo agrícola en un arte auténtico enriquecido a lo largo de los siglos.

11 CHECA, F. (1994), «La teoría del jardín en la España del Renacimiento», en VV.AA.: El Bosque de Béjar y las villas de recreo en el Renacimiento. Actas de las Jornadas, Salamanca, 37-45, p. 39. 
pintura, lo que le permitirá crear todo el vocabulario del jardín barroco y llevar a cabo sus máximas realizaciones. Pero este genio del jardín nunca escribió ni una sola línea de teoría. Sin embargo Boyceau, en su Traité du jardinage selon les raisons de la nature et de l'art (París, 1638), enuncia ya los postulados básicos del jardín francés: simetría y variedad, elección del sitio con criterio estético y funcional, importancia del agua, etc. El jardín no es ya de los médicos, boticarios, etc., sino de reyes, príncipes y nobles que recurren a artistas especializados para su realización ${ }^{12}$.

En España, Francisco Miguel Agustín escribe el Libro de los Secretos de Agricultura, casa Rústica Pastoril (Perpiñán, 1626), que será varias veces reeditado, incluso en la siguiente centuria, hasta $1781^{13}$. También podemos citar el Tratado de Agricultura de José Martín Fuentidueñas, arbolista del Buen Retiro durante el siglo XVII, que diferencia entre planteles, plantíos y huertos y dedica unas líneas a definir unos rasgos muy generales de jardines ${ }^{14}$.

Llegados al siglo XVIII tendríamos, por un lado, la enorme influencia del jardín francés clásico simbolizado por la obra de Le Nôtre y codificado en el tratado de Dézallier D’Argenville, Théorie et la pratique du jardinage (París, 1709), reeditado numerosas veces hasta 1764 en francés, alemán e inglés, y, por otro lado, toda la incipiente teoría sobre el nuevo jardín paisajista. En España se puede apreciar la influencia combinada de las dos tendencias, por ejemplo en los jardines de La Granja donde aparecen reproducidos claramente elementos codificados en el tratado francés a la vez que se desarrolla enseguida un cierto gusto casi místico por la naturaleza. Por otro lado, el siglo XVIII es el siglo de oro de la botánica española; comienzan las grandes expediciones y se crean los jardines botánicos más importantes. Esto tiene gran relevancia, ya que la evolución de la aplicación de la botánica en la horticultura es inseparable de la historia del jardín. Continúa también la literatura agrícola en este siglo, por ejemplo con la recopilación de Andrés Buriel, Fragmentos de dos obras grandes de todas las partes de Agricultura y cría de animales (Toledo, 1752), donde se recogen las obras de Francus Xaverius y Jacobo Palominus ${ }^{15}$.

Pocos son los libros específicos de jardines que se traducen en el siglo XVIII en España, pues se manejaban generalmente las ediciones originales francesas, por lo que se exigía que los maestros jardineros supieran francés ${ }^{16}$. Recordemos que casi todos los jardineros que están trabajando para la monarquía durante este siglo son de

12 AÑón, C. (1987), «El arte del jardín en la España del siglo XVIII», El Real Sitio de Aranjuez y el arte cortesano del siglo XVIII, catálogo de la exposición, C.A.M., Madrid, 255-270, p. 256.

13 BONET CORREA, A. (1988), Bibliografía de arquitectura, ingeniería y urbanismo en España (1498-1880), Madrid, tomo I, pp. 53-55.

14 Tovar, V. (1988), «Consideraciones al valor de lo rústico en los Sitios Reales (reinando Carlos III)», Fragmentos, 12-13-14, 219-231, p. 222.

15 Ibidem.

16 Todavía en el siglo XIX se exige a los estudiantes del ramo saber francés, pues gran parte del vocabulario de la profesión procede de dicho idioma. 


\section{LA TEORÍA Y LA TRATADÍSTICA DEL JARDÍN EN ESPAÑA DURANTE EL SIGLO XIX}

origen francés y que también la gente ilustrada encargaba numerosos libros de todo género directamente a Francia, como por ejemplo es el caso de la condesa-duquesa de Benavente, creadora del más impresionante y moderno jardín en la España dieciochesca. Las obras que se ejecutaron, los proyectos realizados, los tratados recomendados por don Antonio Ponz, los índices de las Bibliotecas reales y particulares, demuestran que se manejaban tratados extranjeros. Carmen Añón se lamenta de no haber podido encontrar un solo libro que tratase específicamente de jardinería en los últimos treinta años del siglo XVIII ${ }^{17}$. Habría que remontarse al Espectáculo de la Naturaleza, o conversaciones acerca de las particularidades de la Historia Natural... de Nöel Pluche, traducido al español desde 1774 a 1775 por Esteban Terreros y Pando, que dedica su tomo II (de los dieciséis con los que contaba) especialmente a los jardines siguiendo un estilo didáctico en forma de diálogo. Repasa las flores y sus características, los elementos del jardín y la forma de organizarlo. Nos remite a Cicerón, Horacio, Columela y Plinio defendiendo una tendencia naturalista dentro del jardín, pero aportando unas ilustraciones aburridamente formales ${ }^{18}$.

En este siglo abundan, sin embargo, en España las obras sobre Historia Natural, como la del irlandés Bowles, Introducción a la historia natural y a la geografía física de España (1786), o la de nuestro naturalista ilustrado Cavanilles, Observaciones sobre la historia natural, geografía, agricultura, población y frutos del reyno de Valencia (1795). Estudiando este tipo de obras se puede comprender cómo la cultura del setecientos iba desgranando paulatinamente los elementos que conformarán una nueva imagen de la naturaleza ${ }^{19}$, que también estará relacionada con la nueva apreciación del paisaje y del jardín pintoresco que se está introduciendo en España durante esas décadas.

Efectivamente, la moderna imagen del mundo natural cuenta con tres componentes esenciales ${ }^{20}$ : por un lado la sustitución de las concepciones estáticas de la tierra por otras de carácter dinámico; por otro lado, la visión del papel del hombre como agente transformador de los procesos naturales que hace que a partir del pensamiento ilustrado la naturaleza no pueda ser descrita como algo ajeno a la sociedad humana, la huella del hombre es visible en la tierra; $y$, por último, lo más interesante para nosotros, que es el desarrollo de una consideración estética de la naturaleza.

El marco natural será visto como paisaje y consecuentemente como fuente de goces y emociones. Se le atribuye una cualidad estética al entorno natural y al paisaje humanizado, a la vez que se difunden categorías como lo «bello» y lo «sublime» o lo

\footnotetext{
17 AÑón, C. (1988), «Armonía y ornato de la naturaleza en el Madrid de Carlos III», en Carlos III. Alcalde de Madrid, Ayto. de Madrid, 129-176, p. 137.

18 Ibidem.

19 Cfr. URTEAGA, L. (1987), La tierra esquilmada. Ideas sobre la conservación de la naturaleza en la cultura española del siglo XVIII. Ed. Serbal, C.S.I.C., Madrid, 174-188.

20 Ibidem, p. 174.
} 


\section{EVA J. RODRÍGUEZ ROMERO}

«pintoresco» para calificar determinados parajes. De todas formas, los viajeros ilustrados no veían el paisaje tal y como lo percibimos actualmente, sino más bien como vistas, pero en todo caso para ellos la tierra se podía convertir «en un maravilloso espectáculo» y en sus páginas se vislumbra numerosas veces la admiración y el disfrute que sienten por el entorno que están describiendo. El paisaje es para ellos una fuente de sensaciones, entre las cuales las más placenteras son las que les produce el paisaje humanizado, el terreno «hermoseado» por la acción del hombre ${ }^{21}$. Se conjugan lo «bello» y lo «útil» en los campos labrados, los frutos dispuestos para la cosecha, etc., en suma, lo que más aprecian es el paisaje «pintoresco».

Esta apreciación de la belleza del paisaje cuando está tocado por la mano del hombre, cuando es provechoso para el alma y para la industria, es la causa del fomento y la protección del arbolado, que tan patentemente queda reflejada en la obra de Antonio Ponz ${ }^{22}$ que dedica todo el prólogo del tomo IX de su Viaje de España a los árboles. Para los viajeros y para los naturalistas del siglo XVIII no hay paisaje bello sin árboles. Ponz pide repetidas veces una legislación sobre arbolado con el criterio debido y, como esta tarda en llegar, toma sobre sí la responsabilidad y ensarta todo un tratado de plantación de árboles escrito ex profeso para el Viaje por su amigo, botánico y jardinero de los Reales Sitios, Casimiro Ortega ${ }^{23}$. Pero el arbolado no es lo único que fomenta Antonio Ponz en relación con los temas que nos incumben, sino que es uno de los primeros españoles que describe y califica positivamente los jardines paisajistas ${ }^{24}$. En cuestiones teóricas sobre el jardín, Ponz recomienda a Laugier, que en su Essai sur l'Arquitecture (París, 1753) dedica un extenso capítulo a la jardinería, donde critica los jardines de Versalles que le producen aburrimiento y defiende formas más naturalistas.

\section{EL JARDÍN EN LAS GUÍAS, LIBROS DE VIAJES Y TRATADOS DE ARQUITECTURA.}

Como acabamos de ver, a finales del siglo XVIII ya habían penetrado en España las primeras referencias sobre los jardines paisajistas, mediante el manejo de libros extranjeros y reflejados en las páginas de los viajes de Ponz. Durante el siglo XIX seguirán teniendo mucha influencia en el mundo del jardín las guías de viaje y las descripciones de lugares y ciudades. Desde 1804 aparecen descripciones y estudios de los jardines históricos de la monarquía, monografías sobre los Sitios Reales, etc.

\footnotetext{
${ }^{21}$ Ibidem, p. 181.

22 Ver al respecto, PUENTE, J. de la (1968), La visión de la realidad española en los viajes de don Antonio Ponz, ed. Moneda y Crédito, Madrid, pp. 78-92.

${ }^{23}$ En el tomo XIII del Viaje de España, pp. 1134-1150.

24 Aparecen numerosas descripciones de jardines paisajistas en la obra de PONZ, A. (1785), Viaje fuera de España, 2 tomos. Ed. Aguilar, Madrid, 1988.
} 


\section{LA TEORÍA Y LA TRATADÍSTICA DEL JARDÍN EN ESPAÑA DURANTE EL SIGLO XIX}

Ya entre 1775 y 1776 se publicó una colección de vistas dirigida por Domingo de Aguirre, titulada Planos y vistas de Aranjuez, que representa en su mayor parte el lado rural y productivo de dicho Real Sitio: aparecen la Casa de Vacas, una vista general desde la Casa de Mira el Rey y desde el camino de Ocaña, el Campo Flamenco, etc... Queda plasmado en estas imágenes el sentimiento del paisaje, pero sin embargo no se presta atención ninguna a los jardines. Donde sí se les da muchísima importancia es en la Descripción Histórica del Real Bosque y Casa de Aranjuez ${ }^{25} \mathrm{de}$ Álvarez de Quindós y Baena, aparecido en 1804. La parte cuarta del libro «Su frondosidad, producciones y riegos» se dedica íntegramente a estudiar los Jardines del Palacio, el Jardín del Príncipe y el de la Primavera, otros jardines, huertas y plantíos, las diversas labores que se llevan a cabo en el Sitio, los animales extraños que hubo en Aranjuez y los diversos caces. Es una visión muy completa, tanto de la historia de Aranjuez, como de la situación de los jardines y planteles a comienzos del siglo XIX y pone en valor tanto los jardines «artísticos» como la faceta productiva del lugar que conecta el interés ilustrado por la agricultura con el interés utilitario de la ciencia decimonónica. En 1825 se publica el Compendio Histórico, Topográfico y Mitológico de los Jardines y Fuentes del Real Sitio de San Ildefonso, de Sanmartín Sedeño, que será reeditado en 1845.

En la década de los veinte, Fernando VII encarga a su pintor de cámara, Fernando Brambilla, unas vistas de los Reales Sitios para adornar diversos aposentos palatinos y, también por deseo regio ${ }^{26}$, estos cuadros se litografían en setenta y cinco láminas que se pusieron a la venta entre 1827 y $1832^{27}$. En 1833 se añaden trece láminas con vistas de la capital ${ }^{28}$. Tras la muerte del rey, la reina Gobernadora se encarga de continuar esta empresa y así, en 1835 , se publica la colección completa de litografías ${ }^{29}$ con la intención de dar a conocer en España y en Europa los «sitios pintorescos a que

\footnotetext{
25 Imprenta Real, Madrid, 1804.

${ }^{26}$ Seguramente para dar a conocer la labor que se había llevado a cabo de recuperación y mejora de los Sitios Reales tras la Guerra de la Independencia. Estos lugares eran famosos incluso fuera de España, por lo que debían considerarse como símbolos de la monarquía. En el anuncio que el Real Establecimiento Litográfico publicó para su difusión se decía: ... «La magnificencia de los Sitios Reales... es célebre, no solo en España, sino también en todo el mundo civilizado. Cosa muy singular, y de que tal vez no se hallará ejemplo alguno fuera de España, es la inmensa diferencia que existe entre todos ellos, á pesar de hallarse a tan corta distancia unos de otros, no solo en el carácter arquitectónico de sus palacios, sino hasta en su clima y en la vegetación de su suelo.» (Citado por PARDO CANALís, E. (1972), «La Colección de las Vistas de los Sitios Reales y Madrid», Revista de Ideas Estéticas, 119, 19-30, p. 21).

27 Colección de las Vistas de los Sitios Reales litografiadas por orden del Señor D. Fernando VII de Borbón, Real Establecimiento Litográfico, 1827-1832.

28 Vistas de Madrid litografiadas por orden del Rey de España el Señor D. Fernando VII de Borbón, Real Establecimiento Litográfico, 1833.

29 Colección de las Vistas de los Sitios Reales y Madrid litografiadas por orden del Señor D. Fernando VII de Borbón, Real Establecimiento Litográfico, 1835, 88 láms.
} 
la naturaleza y el arte han dado celebridad» ${ }^{30}$. Se justifica la agregación de Madrid a San Ildefonso, San Lorenzo y Aranjuez porque «... presenta... en los soberbios edificios del Real Palacio y del Real Museo, en los jardines del Buen Retiro..., en las orillas del Manzanares y en las hermosas montañas del Guadarrama que a lo lejos lo rodean, puntos de vista muy interesantes. En todos estos lugares se disfrutan hermosas perspectivas donde el arte vence a la naturaleza.» ${ }^{31}$

A mediados de siglo, en 1845, Fagoa y Muñico escriben la Descripción de los Reales Sitios de San Ildefonso, Valsaín y Riofrio y en 1863 se publica Un viaje al (sic) Escorial. Descripción ordenada del Monasterio y Palacio y de las modernas casitas del Infante y del Príncipe de José Martín y Santiago, a modo de guía de viaje.

Aranjuez vuelve a ser «motivo de actualidad» con la Historia descriptiva del Real Sitio de Aranjuez escrita en 1868 por don Cándido López y Malta sobre la que escribió don Juan Álvarez de Quindós (Imprenta de D. Cándido López, Aranjuez, 1869), que recoge, como indica el título, la obra anterior, pero incluye las nuevas transformaciones que tuvieron lugar durante la primera mitad del siglo XIX tanto en el pueblo como en los jardines y los alrededores. Esto la convierte en una obra imprescindible para estudiar el contraste que existe entre las diversas maneras de entender el jardín, desde el origen renacentista, pasando por el trazado barroco y las diversas actuaciones neoclásicas, hasta llegar al jardín isabelino que transforma la imagen del Parterre, nexo de unión entre palacio y ciudad, e invade la expansión del Sitio como expresión de la jardinería privada en los palacetes que la nobleza está erigiendo en esas fechas.

Martínez Ginesta en el capítulo «Estética de la vegetación», en el Madrid Moderno (1880), se hace eco de que «el gusto moderno se ha decidido por el jardín natural, a la inglesa, porque se presta a más variedad, y la imaginación goza con los múltiples efectos que la vegetación presenta por todos lados», mientras que el jardín tradicional «está sometido a una rigurosa planimetría que violenta en cierto modo a la natural belleza y desarrollo de las plantas» aunque «se armoniza bien con las formas arquitectónicas de los grandes edificios» ${ }^{32}$. Como vemos, a finales de siglo se sigue apreciando el jardín paisajista como contrapuesto al jardín regular, aunque el argumento esgrimido no sea la conveniencia estética del mismo por sus características formales, sino los efectos de la vegetación dispuesta de manera semejante a la vegetación salvaje y no tallada o recortada o siguiendo rígidas alineaciones como sucede en el jardín geométrico.

No sólo en las guías y libros de viaje encontraremos referencias teóricas y descripciones de jardines, sino que también se aborda el tema en algunos tratados de arquitectura y en libros de láminas arquitectónicas. Así, es muy relevante la defensa

\footnotetext{
${ }^{30}$ Según el prospecto anunciador. Ver nota 26.

31 Ibidem.

32 Ibidem., pp. 274-275.
} 


\section{LA TEORÍA Y LA TRATADÍSTICA DEL JARDÍN EN ESPAÑA DURANTE EL SIGLO XIX}

que hace Jovellanos del jardín pintoresco, que conlleva todos los elementos del emocionalismo y el asociacionismo, en su Carta sobre la arquitectura inglesa y la llamada ultramarina $(1808)^{33}$. Por su parte, Manuel Fornés y Gurrea escribirá en 1846 El arte de edificar y el Álbum de proyectos Originales de Arquitectura, donde dedica algunos de sus proyectos a una «Casa de Recreo para un Grande» con «figuras y juguetes simbólicos, sorprendentes por sus caprichos y bellezas artísticas», una «Casa de campo y jardín para un hacendado que necesite despejar la imaginación atareada en negocios de peso y trascendencia» ${ }^{34}$. Refleja así el auge de las residencias suburbanas o campestres en los años centrales del siglo pasado y recoge con cautela los valores escénicos de la jardinería que prima en esos años. Un poco más tarde, en 1857, Luis Rigalt publicará el Álbum Enciclopédico-pintoresco de los industriales. Colección de dibujos geométricos y en perspectiva de objetos de decoración y ornato, en los diferentes ramos... ${ }^{35}$ donde recoge multitud de diseños de elementos para jardines en los más variados estilos y que se podrían fabricar en serie.

\section{EL JARDÍN EN LAS PUBLICACIONES PERIÓDICAS.}

También es fundamental, sobre todo por sus aportaciones gráficas, el mundo de las publicaciones periódicas, como la revista La Ilustración Española y Americana y el Semanario Pintoresco Español. La primera reflejaba los progresos de la jardinería urbana, sobre todo en el Retiro de Madrid, escenario de exposiciones nacionales e internacionales, que eran siempre puntualmente recogidas por este tipo de revistas. Este tipo de prensa, cuyo florecimiento se enmarcó entre las dos Desamortizaciones (Mendizábal, 1835-1836 y Madoz, 1855), tuvo una enorme repercusión en el panorama cultural del país. El Semanario Pintoresco Español tenía un claro papel pedagógico, había que instruir y educar en el gusto por el arte y lo espiritual a «todas las clases de la sociedad», y en este sentido aquellas primeras publicaciones divulgativas

33 Citada por HenARES, I. y CAlATRAVA, J. (1982), Romanticismo y teoría del arte en España. Ed. Cátedra, Madrid, p. 22. En el origen del romanticismo se encuentra la teorización del jardín pintoresco que crea un nuevo tipo de relaciones entre sujeto, realidad sensible y cultura, relaciones que quedarán definidas por la mecánica más típica del psicologismo: el asociacionismo. Una de las consecuencias de esto será, por ejemplo, la recuperación histórica del gótico.

34 FoRnÉS Y GURREA, M. (1846), Album de proyectos Originales de Arquitectura. Ed. Poniente, con introducción de Antonio Bonet Correa, 1982, pp. 95 y 105. Citado por SoTO, V. (1994), «Narciso Pascual y Colomer, el marqués de Salamanca y los jardines madrileños del periodo isabelino» en $E l$ palacio del marqués de Salamanca. Ed. Argentaria, Madrid, p. 64.

${ }^{35}$ Litografía de la Unión, Barcelona, 1857. Es un amplio repertorio de grabados de todo tipo de elementos ornamentales para arquitectura y jardines, incluyendo diseños de casas, quioscos, verjas... clasicistas, rústicas y goticistas; parterres, lagos irregulares, jarrones de jardín, trazados en estilo mixto, etc... 
presentaban una clara preocupación por la «culturización» del país ${ }^{36}$. Muchos de sus artículos han servido numerosas veces como fuentes para estudiar las más diversas manifestaciones artísticas, especialmente las que no han podido perdurar hasta nuestros tiempos ${ }^{37}$.

Algunos de los artículos que aparecían en ellas versaban sobre aspectos prácticos, científicos e incluso teóricos del mundo del jardín. Por ejemplo, Luis Álvarez Alvistur escribía un artículo titulado «Animales y vegetales que deben figurar en los jardines de aclimatación» ${ }^{38}$ que es un listado comentado de todo tipo de animales de los cinco continentes, tanto mamíferos, como reptiles, aves e insectos, así como de semillas, tubérculos y pies vivos de plantas y sus variedades, tanto útiles como ornamentales, que debería contener como mínimo un jardín de aclimatación. En la sección de Economía Rural del Semanario Pintoresco Español, aparece un interesante artículo de José Echegaray: «De la aclimatación de las plantas» ${ }^{39}$, donde se estudian los diversos climas de la Península. La variedad de éstos hace posible que se puedan aclimatar en nuestro suelo todo tipo de plantas foráneas. En el artículo anónimo «Jardines Chinos ${ }^{40}$ se comparan los jardines europeos con aquéllos en una visión más realista que la de los legendarios jardines chinos que constituyeron el origen del jardín paisajista. En Europa los jardines reúnen cuanto ha repartido la naturaleza en las diferentes regiones y todo está calculado para el recreo y la utilidad. Sin embargo, los jardines chinos se componen de cuadros separados por pequeños muretes en los que hay tiestos, con senderos entre ellos apenas recorribles. Los estanques son de agua estática y abundan las escaleras y aposentos. Le llama la atención el interés de los chinos por producir especies enanas, e incluso bosques en miniatura, y también su amor a las flores, que supera incluso al de los holandeses.

No falta de vez en cuando en estas revistas una nota galante, como por ejemplo el artículo «El lenguaje de las flores», que proporciona un listado de flores y su significado simbólico ${ }^{41}$, lo cual era muy útil para ciertos juegos de sociedad. Tampoco están

${ }^{36}$ Henares, I. y Calatrava, J. (1982), Romanticismo y teoría del arte en España, Ed. Cátedra, Madrid, p. 15.

37 Por ejemplo, las arquitecturas efímeras levantadas en acontecimientos conmemorativos o diversas celebraciones, como queda reflejado en el artículo «Descripción de las Fiestas Reales celebradas en Madrid, con motivo del casamiento de S. M. la Reina Doña Isabel II y de la Serma Sra. Infanta Doña Luisa Fernanda», Semanario Pintoresco, 1846, pp. 353-355. Se ilustra con un grabado de la Iluminación del Prado que presenta una puerta, arcadas y farolillos chinescos. También fueron de inspiración orientalista el castillete de fuegos de artificio que se montó en el cruce de la calle de Alcalá con los paseos del Prado y de Recoletos, y los ciento diez «tipos» orientales, egipcios, chinos, etc. que desfilaron ante SS.MM.

38 En La Ilustración Española y Americana, $\mathrm{n}^{\circ}$ XXXVII, 8 de octubre de 1883, pp. 201-204.

39 EChegaray, J. (1836), «De la aclimatación de las plantas», Semanario Pintoresco Español, pp. $47-48$.

40 «Jardines Chinos», Semanario Pintoresco Español, 1836, pp. 299-300.

${ }^{41}$ HESSE, E. W. (1836), «El lenguaje de las flores», Semanario Pintoresco Español, pp. 87-88. 


\section{LA TEORÍA Y LA TRATADÍSTICA DEL JARDÍN EN ESPAÑA DURANTE EL SIGLO XIX}

ausentes las crónicas de exposiciones, como la «Jardinería en la Exposición Industrial de París» donde se reproduce un grabado de una pajarera entre plantas exóticas ${ }^{42}$.

De 1836 a 1846 aparecen una serie de artículos sobre los Sitios Reales en diversas secciones del Semanario Pintoresco Español - Madrid pintoresco, España pintoresca, Madrid artístico - en los cuales se presta especial atención a los jardines y fuentes ${ }^{43}$. Muchos de los grabados de estos artículos han servido para conocer el estado de los jardines en el siglo XIX, que de otra forma se hubiesen perdido al ser transformados $\mathrm{o}$, incluso, al haber desaparecido.

\section{OBRAS DE TEORÍA Y TRATADOS DE JARDINERÍA.}

Nos centraremos ahora en las obras de teoría y tratados de jardinería que se manejaron en España durante la pasada centuria. La primera obra se trató de una traducción del libro extranjero de $\mathrm{C}$. Bailly, Manual completo, teórico y práctico del jardinero o arte de hacer y cultivar toda clase de jardines... traducido por José Carrica y Baucis, que constaba de dos volúmenes y se publicó en Madrid en el año 1830. En esta década alcanzó gran divulgación en España el manual L'Art de composer et décorer les jardins (París, 1834) de Boitard ${ }^{44}$ que trata de jardines exóticos y jardines públicos, laberintos, plantas, juegos de agua, puentes pintorescos y rústicos, pabellones, etc., es decir, abarca desde cuestiones relativas al trazado del conjunto del jardín hasta los más variados elementos de amueblamiento y escenografía del mismo.

Conforme avanza el siglo XIX se va viendo la necesidad de divulgar los más diversos conocimientos sobre jardinería $\mathrm{y}$, con este interés pedagógico, a lo largo de todo el año de 1840 aparecerán en la parte no oficial del Boletín Oficial de Madrid, desde el 4 de julio al 29 de octubre, toda una serie de artículos sobre jardinería y agricultura de jardines. Desde números anteriores, ya en 1839, aparecían muchos artículos sobre agricultura en general, bajo el epígrafe de «Diccionario de agricultu-

42 TAHAN (1855), «Jardinería en la Exposición Industrial de París», Semanario Pintoresco Español, pp. 332-333.

43 Entre otros:

— El CURIOSO PARlante (1836), «Buen Retiro», Semanario Pintoresco Español, pp. 51-53.

- PARDO, E. (1837), «Las fuentes del Prado», idem, pp. 212-214.

— «Las fuentes de la Granja» (1838), idem, pp. 775-778.

- El CuRioso Parlante (1840), «Los jardines reservados del Buen Retiro», idem, pp. 209-212.

- FORONDO, M. (1845), «El Real Sitio de Aranjuez», idem, pp. 169-170.

— VERA, J. de (1845), «El Real Sitio de San Ildefonso», idem, pp. 249-255.

— «La Casa de Campo» (1846), idem, pp. 361-362.

44 RodrígueZ DE RIVAS, M. (1955), p. 9. 


\section{EVA J. RODRÍGUEZ ROMERO}

ra» firmados por un tal D. de la A., abarcando los más diversos temas del ramo ${ }^{45}$. Así, en los números 1132-1134 (1840) se estudian los diversos tipos de «emparrados», tanto ornamentales, como de frutales y vid, que se pueden construir en un jardín.

Después comienzan las entregas de una Agricultura de los Jardines dentro de la cual se dedican varias partes en total a los «jardines de flores» $\left(\mathrm{n}^{\text {os }} 1173,1176\right.$ y 1177,1840 ), empezando con aspectos generales como la situación del jardín, la calidad de la tierra y el modo de prepararla, hasta los objetos necesarios en el jardín y el tiempo de la siembra agrupados en tres secciones que forman un capítulo. El segundo capítulo, «De los jardines de placer» se divide también en varias secciones y entregas, diciéndose que:

En estos es en los que se reune el lujo á la bella naturaleza; en los que el arte se empeña en ostentar la riqueza de sus producciones... no vemos en ellos más que líneas rectas, calles de árboles que se pierden de vista... follages de árboles desfigurados por las tigeras; en una palabra, no hallamos más que el disgusto que inspira la naturaleza contrariada y violentada por la torpe mano del jardinero ignorante... He aquí porque los propietarios abandonan sus parques simétricos, y prefieren el pasearse por los campos, donde hallan una sencillez agradable, una variedad hechicera, un desorden precioso, bellezas siempre nuevas, en una palabra, la naturaleza que han desterrado de sus posesiones ${ }^{46}$.

Se ve claramente la preferencia del autor por los principios del jardín paisajista, aunque se disponga a hablar de los jardines regulares, refiriéndose a ellos en los mismos términos que desde el comienzo de la revolución jardinera venían utilizando todos los escritores y teóricos: árboles mutilados por tijeras, naturaleza contrariada con líneas rectas, etc., frente a la variedad, la sencillez y la sorpresa... que se encuentra en los campos y se puede reproducir en un jardín paisajista o «natural». También hará referencia al tema de las vistas lejanas, del entorno del jardín, cuando expresa:

Los planos de los jardines que se han de formar en terrenos llanos son mas fáciles de formar, pero se hallan privados de uno de los más bellos adornos, que es el que hermosea todos los demas, cual es el de la vista, que no puede suplirse con los paseos mas hermosos, ni con todo el lujo y magnificencia imaginables. El aire de las colinas siempre es mas puro... y la vista no pierde ninguno de los objetos que puedan causarle placer... ${ }^{47}$

\footnotetext{
45 Hay lo menos diez artículos sobre el cáñamo, sobre la creta utilizada como abono y para las artes («blanco de España»), sobre las propiedades medicinales de las plantas, sobre criadillas de tierra, sobre desgrane, sobre la electricidad, sobre las encinas desde el punto de vista botánico y desde el punto de vista de su cultivo, sobre «deslechugar», sobre emparrados, sobre el modo de empollar, sobre el arte de la destilación, etc.

46 Boletín Oficial de Madrid, $\mathrm{n}^{\circ} 1177,1840$, p. 3.

47 Ibidem, p. 4.
} 
Sin embargo, a continuación, y citando como fuente el tratado de Leblond $(s i c)^{48}$, aborda las disposiciones generales de un jardín clásico, con sus parterres, sus fuentes, sus calles, galerías, anfiteatros, canales, laberintos, etc., recomendando en todo caso variedad y diversidad entre las diversas piezas pétreas y vegetales ${ }^{49}$.

En los cuatro siguientes números del Boletín (1179-1182) realiza toda una exposición de los principios fundamentales del jardín paisajista, bajo el título de «De los jardines ingleses». Comienza con una breve historia sobre ellos, donde señala a chinos y japoneses como los inventores de éstos, siguiendo un tratado que cita ampliamente, del cual no da ni el título ni el autor; tan sólo dice que fue publicado en Londres en 1757, por lo cual deducimos que se trata de Desings of Chinese Buildings (Londres, 1757) de William Chambers, que no publicará hasta 1772 su obra más conocida, A dissertation on Oriental Gardening. Quizás nuestro camuflado autor tuviese también noticias del tratado de Le Rouge (Paris, 1776-1787), que atribuía el origen de los jardines paisajistas a los chinos y su difusión a las descripciones de los jesuitas franceses, relegando a Kent a mero recreador del estilo en Inglaterra, a imitador de los chinos. Así dice, «Hacia el año 1720 apareció Kent, hombre de genio y artista de mucho gusto; presentó á Inglaterra, pueblo amigo de la naturaleza, la naturaleza misma en la composición de los jardines...» y añade «El gusto de los jardines llamados Ingleses, que mas bien deberían llamarse Chinos, abraza hoy todo el continente» ${ }^{50}$.

Sí cita, sin embargo, ciertas fuentes, que suponemos estuvieron a su alcance, como «El arte de los jardines modernos» (París, 1771, 8 vol.) que por el título podría ser el de Le Rouge, pero confundido de fecha, «Ensayo sobre los jardines»(1774) de Watelet, «Teoría de los jardines» (1776), la obra de Girardin (1777) y el «Poema de los jardines» del Abate de Lille. Por otra parte recomienda a los aficionados visitar Ermenonville, les alerta sobre los peligros de amontonar demasiados objetos en pequeños jardines y, como muestra de buen hacer, describe a lo largo del resto del capítulo y en el capítulo siguiente ( $\left.{ }^{\circ} 1180-1181\right)$ los jardines de Stowe, ya que su conocimiento «bastará para dar una idea de lo que merece el nombre de jardín natural». Termina su estudio sobre los jardines paisajistas en el $\mathrm{n}^{\circ} 1182$, donde concluye diciendo que no dará más reglas porque «es inútil meterme en mayores menudencias... Las reglas son útiles para las imaginaciones frias, cuando se trata de objetos y convenciones; pero en los jardines ingleses no caben objetos de convención, porque todo debe ser natural en ellos, subordinado al sitio, á sus accidentes, y á los objetos que le rodean»

Tras un breve lapso de tres números, se retoma el hilo de la agricultura de jardines, dedicando seis entregas al riego $\left(\mathrm{n}^{\mathrm{os}} 1186-1188,1191\right.$ y $\left.1193-1194\right)$; seis intitu-

\footnotetext{
${ }^{48}$ LE Blonde, A. (1722), La Théorie et la Pratique du Jardinage, Paris. Uno de los tratados más difundidos de los que codifican los principios del jardín barroco, aportando todo tipo de soluciones para los más diversos elementos del jardín regular, que serán repetidas una y otra vez.

49 Boletín Oficial de Madrid, $\mathrm{n}^{\circ} 1178,1840$, pp. 3-4.

50 Boletín Oficial de Madrid, $\mathrm{n}^{\circ} 1180,1840, \mathrm{p} .3$.
} 
lados «De la poda» ( $\left.{ }^{\text {os }} 1195-1200\right)$ constituyen un exhaustivo estudio de las técnicas y tipos de podas refiriéndose a espalderas, árboles exentos, setos, frutales, injertos, etc.; once números $\left(\mathrm{n}^{\mathrm{os}} 1211-1223\right)$ tratan «De los prados», naturales de secano y de riego y artificiales y medios para conseguirlos, describiendo científicamente las gramíneas, tréboles y plantas parásitas de los mismos. El resto del año deja de publicarse esta sección específica de agricultura y jardines, pero en la que la sustituye, «Variedades», aparecen de cuando en cuando temas agrícolas como una experiencia en árboles que habían perdido parte de su corteza $\left(\mathrm{n}^{\circ} 1225\right)$, abonos $\left(\mathrm{n}^{\circ} 1229\right)$ y estiércoles ( $\left.\mathrm{n}^{\mathrm{os}} 1237-1238\right)$, todos ellos firmados por nuestro misterioso $\mathrm{D}$. de la A.

Tenemos motivos para pensar que este personaje es también el autor del hasta ahora anónimo libro Jardinería teórica y práctica, arte de cultivar toda clase de flores y distribuir los jardines con una idea de los llamados ingleses... ${ }^{51}$, pues entre los numerosos aspectos que trata ${ }^{52}$, coincide tanto en estructura como en la redacción de algunos párrafos en concreto. Así, al tratar el tema de los jardines de flores o de recreo, lo organiza, como hemos visto en el caso de los artículos publicados en el Boletín, en idénticos puntos: la situación del jardín, la calidad del terreno, el modo de preparar la tierra y la época de verificar la siembra ${ }^{53}$. En el capítulo «De los jardines ingleses», se define un jardín inglés como:

\footnotetext{
Campiña hermosa por su sitio, rica en vegetación y plantada convenientemente de árboles, cortada por canales, rios ó arroyos, con diversas producciones, hermoseada con masas de que se ha sabido crear utilidad; en una palabra, es la simple naturaleza adornada por todas sus gracias, y ayudada por el arte que no debe distinguirse del todo, sino en algunos detalles de buen gusto ${ }^{54}$.
}

De la misma manera atribuye a chinos y japoneses la invención de este tipo de jardines y cita la historia del Japón de Kaempser donde se describían colinas artificiales con modelos de templos en lo alto, arroyuelos, cascadas y bosquecillos. Según el autor, los chinos observaban la naturaleza existente y según las circunstancias elegían las disposiciones más convenientes, a la vez que ocultaban sus defectos.

51 Imprenta de M. R. y Fonseca, Madrid, 1848 ( $2^{\mathrm{a}}$ ed.). Ejemplar conservado en la Biblioteca Nacional.

52 Contiene capítulos dedicados a las partes de la flor, los tipos de flores, el perfume, la reproducción vegetal, la fecundación artificial, géneros y especies de plantas, instrumentos de jardinería, jardines de flores o de recreo, técnicas de multiplicación de las plantas, cultivo en general y cultivo particular de las plantas con flores, arbustos..., versando el capítulo XII sobre los jardines ingleses. Contiene también un apéndice sobre el cultivo de plantas en tiestos, ventanas, balcones y terrazas, así como arbolillos frutales para tiestos y cajones.

53 Boletín Oficial de Madrid, 1840; $\mathrm{n}^{\text {os }} 1173$, p. 4; 1176, pp. 3-4 y 1177, p. 2. También en Jardinería teórica y práctica... (1848), pp. 56-65.

54 Jardinería teórica y práctica..., (1848), p. 188. Idéntica definición aparece también en el Boletín Oficial de Madrid, n 1179,1840 , p. 2, como comienzo de un capítulo de igual nombre que el del libro. 


\section{LA TEORÍA Y LA TRATADÍSTICA DEL JARDÍN EN ESPAÑA DURANTE EL SIGLO XIX}

Continúa diciendo que, como a los chinos no les gusta pasear, no hay en sus jardines paseos y calles como en los jardines de Europa, sino que el terreno se distribuye en escenas y «los caminos jiran dando vueltas, atraviesan por medio de bosquecillos y guian á diferentes puntos de vista cada uno de los cuales está indicado por un asiento, por un edificio, ó por cualquier objeto» ${ }^{55}$. Constatamos así que nuestro jardinero está al día de las fuentes inglesas y francesas sobre el jardín paisajista, que mantenían una polémica sobre la autoría del jardín natural por parte de los chinos o de los ingleses. Recoge también las ideas de Chambers sobre los diferentes tipos de escenas, risueñas, horribles, encantadas, con animales, con sonidos misteriosos, etc. que conviene distribuir por el jardín para pasar de vistas limitadas a perspectivas de más extensión, pasar de la luz a la sombra y ocultar algunas escenas para producir un efecto sorpresa por «la fuerza con que afectan nuestra alma los contrastes» ${ }^{56}$. Se hace eco igualmente de la referencia de tratadistas ingleses sobre el empleo de caminos rectos por parte de los chinos $^{57}$, pues sería extravagante hacer un camino tortuoso en un terreno llano, aunque se debe aprovechar las irregularidades del terreno y la sorpresa en el recorrido, relacionando la casa con el jardín, el cual debe combinar praderas, bosques, parterres... y cuidar las especies vegetales ${ }^{58}$. También critica el amontonamiento de objetos en un espacio limitado ${ }^{59}$, lo cual sucede muchas veces en Madrid donde se produce una «aglomeración de objetos que todo lo confunden y un gusto fastidioso y pesado en su composición» ${ }^{60}$, con la excepción del jardín El Capricho, al que cita como ejemplo de gusto y modelo perfecto.

Se puede constatar que, en la primera mitad del siglo XIX, la teoría sobre el jardín paisajista en España se reduce a este tipo de manuales que, aunque intercalan asuntos relativos a la filosofía y al trazado de los jardines ingleses, se centran principalmente en temas prácticos sobre el cultivo y los trabajos que requieren los jardines, no sin notas eruditas sobre botánica y fisiología vegetal. Lo mismo venía sucediendo desde 1820 en Inglaterra, sobre todo a partir de las obras enciclopédicas de Loudon, donde

55 Jardinería teórica y práctica..., (1848), p. 189.

56 Ibidem, p. 191.

57 Según CHAMBERS, W. (1772), A Dissertation on Oriental Gardening, los chinos evitan las líneas rectas, pero no las rechazan. Por ejemplo los caminos son construidos prácticamente en línea recta, a menos que un obstáculo se interponga, pues les parece absurdo hacer un camino serpenteante, ya que éstos son trazados por el paso de viajeros y es absurdo que elijan la línea curva para ello. La observación es muy inteligente: sobre un terreno plano, un camino será recto normalmente, pues los caminantes sólo describen curvas sobre terrenos escarpados para suavizar la pendiente. Por lo tanto, el trazar caminos serpenteantes por doquier es totalmente artificioso. Los caminos, además, no son elementos de la naturaleza, implican siempre el paso del hombre, con lo cual no son más naturales por ser curvos que por ser rectos. Quizás en esta observación de Chambers sobre los caminos en los jardines chinos esté la clave para el inicio de la vuelta al jardín regular, que tendrá lugar en el siglo XIX.

58 Jardinería teórica y práctica..., (1848), p. 196.

59 Ibidem, p. 195 y Boletín Oficial de Madrid, $\mathrm{n}^{\circ} 1180$, p. 3.

60 Jardinería teórica y práctica..., (1848), p. 195. 


\section{EVA J. RODRÍGUEZ ROMERO}

la jardinería decimonónica dejará de ser «un arte del gusto» para convertirse en un «arte del cultivo» ${ }^{61}$. Tal situación es la causante de la queja expresada por Melitón Atienza y Sirvent en su Historia de la arquitectura de jardines. Memoria acerca del plan de una obra de arquitectura de jardines, utilidad de esta ciencia y consideraciones sobre la historia y las diferentes escuelas de la jardinería ${ }^{62}$, que manifiesta su desazón porque en un país como España, «uno de los paises clásicos de la jardinería, en el sitio predilecto de la naturaleza, y como escogido por ella para Gabinete de Historia Natural del universo...» no existan tratados serios de jardinería y no se le de importancia a esta ciencia y que «los pocos conocimientos que en él existen... sean debidos á los extranjeros...» ${ }^{63}$. De hecho, su escrito ${ }^{64}$ es una declaración de intenciones sobre una hipotética obra de arquitectura de jardines que él reclama y alienta a que sea escrita. Proporciona para ello un posible plan o índice que abarca aspectos teóricos y prácticos (Consideraciones generales acerca de la historia de los jardines; reglas generales para el trazado y ornamentación de toda clase de jardines; del terreno, agua, clima, vegetales y construcciones como base para la composición; reglas generales de paisaje; trabajos preparatorios del terreno para el trazado; clasificación de los jardines; trazado, distribución y atributos para cada clase y construcciones en que puede intervenir el arquitecto de jardines.) Según dicho esquema, y también por la temática del tercer capítulo, podemos apreciar cómo el autor admite con total naturalidad la posibilidad de realizar jardines siguiendo diversos estilos históricos de los mismos. La primacía del jardín paisajista ha desaparecido y comienza un interés por el estudio de la historia de todos los estilos de jardinería y una vez conocidos y valorados éstos, se podría elegir el más apropiado para cada obra. Esta tendencia sigue las apreciaciones generales de la época del romanticismo, en la cual se revalorizaron los estilos artísticos históricos, lo que permite la recuperación de los jardines regulares, cuyo lenguaje se vuelve a incorporar dentro del mundo del jardín paisajista, bien en algún detalle, bien en ciertas zonas, a la vez que se sigue valorando la naturaleza libre e intacta, lo que supone la continuación del paisajismo, pero con notas eclécticas.

${ }^{61}$ Según la expresión utilizada por CLIFFORD, D. (1970), Los jardines, historia, trazado y arte. Insto. de Estudios de la Admón. Local, Madrid, p. 175, para definir el cambio experimentado en las obras teóricas del jardín en esa centuria, que se centrarán en las novedades botánicas y en los progresos de la agricultura aplicada al mundo de la jardinería.

62 ATIENZA Y SIRVENT, M. (1855), Historia de la arquitectura de jardines. Memoria acerca del plan de una obra de arquitectura de jardines, utilidad de esta ciencia y consideraciones sobre la historia y las diferentes escuelas de la jardinería, Imprenta de Joaquín René, Madrid. El autor era médicoveterinario y catedrático de la Escuela Agronómica de Nogales.

${ }^{63}$ ATIENZA Y SiRVENT, M. (1855), p. 10

64 Que consta de cuatro capítulos, el primero de ellos trata de la «Utilidad de la arquitectura de jardines» ( pp. 7-11), el segundo es un «Bosquejo del plan de una obra de arquitectura de jardines» (pp. 11-12), el tercero aborda una concisa e interesante «Historia de la arquitectura de jardines» (pp. 12-50), para terminar con una «Conclusión» donde clasifica las diversas escuelas de jardines que han existido desde la Antigüedad. 


\section{LA TEORÍA Y LA TRATADÍSTICA DEL JARDÍN EN ESPAÑA DURANTE EL SIGLO XIX}

Melitón Atienza está completamente al día de las tendencias de su época en materia jardinera, tendencias que a comienzos del siglo XX se traducirán en una recuperación generalizada del jardín clásico. Por otro lado, el autor considera que «la utilidad de la arquitectura de jardines se ha hecho hoy indispensable...» ${ }^{65}$ ya que antes «...se abrigaba la falsa creencia de que este arte era casi superfluo, puesto que no se miraba en él mas que las obras de ornato, pero de ningún modo las de utilidad científica, que mas adelante fueron reconocidas y justamente apreciadas ${ }^{66} \mathrm{y}$, una vez más demostrando su actualidad, incluye la «escuela moderna», es decir, los «jardines científi$\cos »^{67}$, como una de las posibilidades, la mejor según él, a seguir.

Asimismo, echa la culpa del estacionamiento que el arte de la jardinería sufre en España a la falta de una formación adecuada de «arquitecto de jardines», puesto que los jardineros «por la falta de libros y de educación científica» necesitaban a los arquitectos o ingenieros para trazar los dibujos de parterres «y estos á su vez se veían en la precisión de consultar á los jardineros» ${ }^{68}$. Atienza y Sirvent enumera los conocimientos que debe tener un arquitecto paisajista de la siguiente manera:

\footnotetext{
El arquitecto de jardines, si ha de llenar... su vasta misión científica... debe familiarizarse con la fábula, y poseer todas las cualidades y conocimientos de los paisajistas... es indispensable que... reuna al mismo tiempo los atributos del pintor y del poeta, siendo este el medio mas seguro de que en sus composiciones pueda imitar la naturaleza, con la naturaleza misma... también debe poseer las nociones suficientes en ciencias naturales ${ }^{69}$.
}

También son muy interesantes algunos de los aspectos que trata, en un tono filosófico-romántico, sobre la historia de la arquitectura de jardines. No habla de la forma del jardín en cada caso, sino de las inclinaciones temperamentales que las motivan en cada país. Así, habla del Paraíso, del origen relacionado con la agricultura, de la sensualidad femenina y su relación con las flores, del amor como aliciente poderoso para el progreso de los jardines... Repasa la jardinería egipcia, siria, fenicia, babilónica, persa y griega, para llegar a China, «pais creador de los artísticos jardines apaisados ó de la naturaleza» ${ }^{70}$. De los romanos destaca que aclimataron vegetales

65 ATIENZA Y SIRVENT, M. (1855), p. 8

66 Ibidem.

${ }^{67}$ Ibidem, conclusiones, p. 56.

68 Ibidem, pp. 7-8.

69 Ibidem, p. 8.

$70 \mathrm{Ibidem}$, p. 19. De Grecia habla del palacio de Alcinoo, de Platón, Epicuro, la Academia de Atenas, los liceos, gimnasios, palestras y bosques sagrados. Como recapitulación se pregunta «¿No observamos también en estos pueblos meridionales mayor exaltación hacia lo bello, y un tacto como instintivo para detenerse delante de aquellos objetos en que la naturaleza ha ocultado alguno de sus prodigios, y que, indudablemente pasarían desapercibidos para otros que no estuvieran inspirados por esa brillante imaginación oriental? (p. 21). 
exóticos traídos de Asia, Persia y Grecia, así como criaron peces en estanques y pájaros indígenas y exóticos cautivos en pajareras. Dedica también varias líneas a los jardines rusos, alemanes y holandeses. De Francia dice que es el país del esplendor y renacimiento de la moderna arquitectura de jardines y cita a Watelet, Dufresny, Morel, Lecourbe, Girardin, Le Nostre (sic), Delille, Thouin y Boitard, lo que demuestra que nuestro autor estaba bien documentado. Nombra a Kent como iniciador de los jardines ingleses hacia 1720, pero prefiere la acepción de jardines anglo-chinos, de los cuales manifiesta su escasez en España ${ }^{71}$. Dedica varias páginas a la arquitectura de jardines en nuestro país, empezando con los jardines árabes de los cuales destaca los adelantos en agricultura (cita los tratados de Aben-Hajaj, Abu-el-Jair, Ebn-elFasel y Ebn-el-Awan), habla de la familia Boutelou y de diversos jardines (Abadía, Aranjuez, Buen Retiro, la Granja, Jardín Botánico de Madrid, jardines de Barcelona y Valencia). Cita las escuelas de jardinería de Nogales, Tudela, Gerona y Aranjuez.

En sus conclusiones distingue tres escuelas de jardines: la escuela oriental, que divide en la china o del jardín apaisado o de la naturaleza y la árabe o pintoresca o arábigo española; la escuela greco-romana de construcciones simétricas, mal llamadas jardines franceses; y la escuela moderna o de jardines científicos. Dice que en España siempre hemos cultivado la escuela greco-romana, poniendo de ejemplo la Abadía con sus fuentes, estatuas y cenadores, ya que él no habla para nada de jardines renacentistas.

Tres años después, en 1858, aparece el libro Tesoro de la jardinería de ventanas, balcones y terrazas o arte de cultivar las plantas en tiestos y cajones y modo de formar jarrones y tapices de verdura 72 , iniciándose toda una serie de publicaciones en esta línea, manuales de floricultura ${ }^{73}$, que son tratados prácticos y no teóricos, aunque en algunos de ellos se indiquen ciertas características de los jardines paisajistas y se den recomendaciones acerca de su disposición. Así, Miguel Colmeiro recomienda «huir de la exageración y de la extravagancia», no realizar jardines pintorescos «pequeños, pues se prestan al ridículo» y basar la composición en las peculiaridades del terreno y en la distribución de la vegetación, «...se necesita habilidad y tacto para colocar y distribuir convenientemente los edificios, que hayan de figurar en un jardín apaisado, huyendo de sobrecargarlo... $\gg^{74}$.

Buenaventura Aragó habla de las características que tienen los jardines paisajistas y de la evolución que sufrieron desde la segunda mitad de la centuria para adaptarse

71 Ibidem, p. 50.

72 Imprenta de Ramón Campuzano, Madrid, 1858.

73 Por ejemplo: YSABEAU, V. F. A. (1872), El jardinero de los salones o arte de cultivar las flores en las habitaciones, en las ventanas y los balcones, por... Vertido del francés al español por D. José Brun y Pages, Madrid, $2^{\mathrm{a}}$ ed. y JAZMín, F. (1882), El lenguaje de las flores y de las frutas..., Barcelona, $3^{\mathrm{a}} \mathrm{ed}$.

74 COLMEIRo, M. (1859), Manual Completo de Jardinería, arreglado conforme a las más modernas publicaciones y dispuesto para el uso de los españoles, varios vols., Madrid, p. 412. 
al nuevo sentido democrático que adquiere la jardinería a lo largo del siglo XIX, en los siguientes términos:

\begin{abstract}
Los jardines naturales en Inglaterra, pero más todavía en el continente, experimentaron en nuestros últimos tiempos notables modificaciones, como por ejemplo, las calles, que en un principio eran muchas e intrincadas de mil maneras, como en los jardines chinescos ahora se limitan a las que son indispensables para facilitar un cómodo y ameno paseo, por no cortar demasiado el terreno. Las curvas de esas calles que se desplegaban inciertas y trazando sinuosidades, ahora se desarrollan de un modo más grandioso produciendo un mejor efecto... los grandes grupos de árboles se encuentran más reunidos, según sus diversas especies y respectivas gradaciones de tintas, para dejar grande espacio a las alfombras de césped... los objetos de decoración, como grutas, templetes, salones de descanso y semejantes, deben ser también rigurosamente introducidos con gusto y buena distribución para no impedir los puntos de vista y disminuir así el efecto total...75.
\end{abstract}

Este autor estaba al día, por tanto, de las últimas tendencias en jardinería que serán responsables de la aparición de los grandes parques en todas las capitales importantes y también en ciudades de provincias que reconvertirán sus antiguas alamedas o campos de mercado en parques públicos. Para él «Los parques no son otra cosa que jardines pintorescos, pero en grande escala» ${ }^{76}$.

Sobre parques versa también el libro de André Lefèvre, Parques y jardines, que será traducido al español por A. Blanco Prieto en $1886^{77}$. Refiriéndose también a los jardines públicos, Muñoz y Rubio ${ }^{78}$ recomienda el jardín mixto, es decir, aquél que combina elementos regulares con zonas paisajistas, «para el mantenimiento del orden y la decencia, y para la buena y fácil circulación de la multitud...». Éste es un signo de la recuperación del jardín geométrico que se está produciendo a finales del siglo pasado.

\title{
EL JARDÍN EN LOS TRATADOS DE AGRICULTURA Y BOTÁNICA.
}

Una vez estudiados todos estos tratados y diversas publicaciones específicos de jardinería, bien teóricos, bien con un enfoque más práctico, es preciso resaltar que fueron mucho más abundantes las publicaciones sobre agricultura, si bien es preciso recordar que éstas mantuvieron siempre una gran relación con el mundo del jardín.

\footnotetext{
75 ARAGÓ, B. (1877), Tratado de jardinería y floricultura, Madrid, p. 21 (Citado por SoTo, V. (1993), «Jardines de la Ilustración y el Romanticismo en España», epílogo de BUTTLAR, Adrian von: Jardines del Clasicismo y el Romanticismo, el jardín paisajista. Ed. Nerea. Madrid, p. 320).

76 ARAGÓ, B., (1877), p. 109.

77 LefÈVRe, A. (1886), Parques y jardines, versión española de A. Blanco Prieto, Barcelona.

78 MUÑOZ Y RUBIO, P. J. (1887), Tratado de jardinería y floricultura. Historia de la jardinería..., Madrid, p. 280.
} 
Los avances en esta ciencia se aplicarán a los jardines y los autores de estas obras son muchas veces jardineros, como los que trabajan en el Jardín Botánico de Madrid. Por otra parte, también algunas obras de botánica y la primera historiografía sobre jardines botánicos tendrá influencia en el jardín decimonónico, que, como hemos visto, muchos teóricos del momento calificaban como el «jardín científico». Consecuentemente, repasaremos las obras de agricultura y botánica que pudieron influir más en el jardín del siglo XIX.

La corriente fisiocrática había sido el origen de la asociación entre la agricultura y el jardín que perdurará también en el siglo XIX. Esta asociación es la causante de que ciertos manuales agrícolas consideren los trabajos del jardinero dentro de la economía rural y a la jardinería como un ramo de la agricultura. Por otra parte, la agricultura permite dominar y transformar la naturaleza y establecer un orden en la superficie de la tierra. Pero si el laboreo del campo establece el principio de la regularidad formal, el jardinero libera al cultivo de su función práctica. Confiere, por tanto, un destino artístico a la agricultura. El jardín convierte el paisaje en una obra de arte, conjuga, pues, ciencia y arte. Ya vimos como en las obras de Historia Natural escritas en el siglo XVIII, los geógrafos y naturalistas apreciaban muchas veces el carácter estético del paisaje y valoraban, sobre todo, los campos cultivados donde era patente la huella del hombre. Otro tanto sucede en los jardines y esto supone un nuevo nexo de unión entre jardinería y agricultura.

Especialmente prolíferos en este campo fueron los Boutelou, sobre todo Claudio, su hermano Esteban y su hijo Pablo ${ }^{79}$, que se dedicarán a investigaciones agronómicas y botánicas más que a la jardinería, ramo en el cual sus anteriores parientes habían sido especialistas. Ya desde 1801 abundan artículos de ellos en revistas especializadas como el Semanario de Agricultura y Artes ${ }^{80}$ o en Anales de Historia Natural. También escribieron numerosos tratados y monografías, monopolizando casi la literațura sobre el tema en la primera mitad del siglo XIX. Así, en 1801 aparece el Tratado de la huerta o método de cultivar toda clase de hortalizas y tres años más tarde el Tratado de las flores, en que se explica el método de cultivar todas las plantas que

\footnotetext{
79 Claudio Boutelou fue desde 1799 jardinero-director del Botánico de Madrid, en 1804 fue ascendido a subdirector del Real Jardín, del cuál fue director durante la invasión francesa, lo que le costó su traslado a la cátedra de agricultura de Alicante, desde donde accedió a la dirección del Jardín de Aclimatación de Sevilla. Su hermano Esteban (III) ocupaba el puesto de jardinero-director del Real Sitio de Aranjuez, como alguno de sus antepasados. Enseñó agricultura en el Real Jardín Botánico de Madrid y también trabajó en Andalucía. Pablo, el hijo de Claudio, fue jardinero-director del Real Alcázar de Sevilla y suplente de su padre como catedrático de botánica y como director de los paseos públicos de Sevilla. Fernando, hermano de Pablo, desempeñó un importante papel en la jardinería española, como profesor de la disciplina y como Director General de Jardines y Bosques de los Reales Sitios desde 1839.

80 Revista fundada en 1797, pasa a cargo del Real Jardín Botánico del Prado en 1804 y se publica hasta 1808 (LÓPEZ LINAJE, J., ed. (1991), De papa a patata. Ed. Lunwerg, Madrid).
} 
sirven para adorno de los jardines ${ }^{81}$, escritos conjuntamente por los dos hermanos, Claudio y Esteban. Claudio Boutelou escribió también un Tratado del ingerto, en que se esplica todo lo correspondiente al arte de ingertar y recogió sus enseñanzas en el campo de la agricultura en el manual Elementos de Agricultura: parte teórica (Madrid, 1817). Por su parte, Esteban Boutelou realizó experiencias de viticultura, publicando una Memoria sobre el cultivo de la vid en Sanlúcar de Barrameda y Xerez de la Frontera (Madrid, 1807) ${ }^{82}$.

Algo más avanzado el siglo, Pablo Boutelou escribirá un interesantísimo estudio sobre la aclimatación de plantas en España ${ }^{83}$, en el cual, después de exponer la definición de aclimatación y sus ventajas, así como los climas que hay en la Tierra y los vegetales propios de cada uno de ellos, pasa a aplicar sus conocimientos al caso concreto de España. Propone los vegetales que sería posible aclimatar en nuestras tierras y posesiones de ultramar según los diversos climas de que disfrutan, las dificultades que supone dicha aclimatación y toda una serie de técnicas y abrigos que se podrán emplear en esa empresa, para terminar con una pequeña historia de los logros conseguidos en España respecto a esta materia.

La última obra en la que colaborarán Claudio y Esteban será en la traducción e introducción del antiguo Libro de Agricultura (2 vol., Madrid, 1878) de Abu Zacaria Ebn-el-Awan.

En esta primera mitad de la centuria también se dedica al estudio de la agricultura el catedrático de agricultura y arbolista mayor de la villa de Madrid, Antonio Sandalio de Arias y Costa, que desempeñaba además el cargo de jardinero mayor del Real Jardín Botánico y dirigía los viveros municipales en el Soto de Migas Calientes ${ }^{84}$. A él se deben las Lecciones de agricultura esplicadas en la Cátedra del Real Jardín Botánico de Madrid en el año 1815 (Madrid, 1818) y la Cartilla Elemental de Agricultura acomodada a nuestro suelo por... (Madrid, 1833).

También desde los años treinta comienza a publicar los resultados de sus investigaciones el eminente botánico Ramón de la Sagra (1797-1871) que trabajó funda-

${ }^{81}$ Recordemos que los manuales de floricultura y sobre plantas de salón y ventana suponen la máxima aportación de la época romántica a la jardinería y tienen que ver con la herencia de los jardines botánicos de Carlos III.

82 Esta memoria es analizada por RuIZ LAGOS, M. (1974), «El botánico madrileño E. Boutelou y el arte y ciencia de la agricultura vinícola jerezana», Anales del Insto. de Estudios Madrileños, 1974, pp. 309-317, donde se citan otros trabajos sobre el tema, como el de ROJAS CLEMENTE, S. de (1807), Ensayo sobre las variedades de la vid común que vegetan en Andalucía, Madrid.

${ }^{83}$ Boutelou, P. (1842), Memoria acerca de la aclimatación de las plantas ecsóticas (sic) por..., Sevilla.

${ }^{84}$ ARIZA, C. (1986 a), «Los jardines madrileños en el siglo XIX», en Madrid en la sociedad del siglo XIX, 2 vol., C.A.M., pp. 519-537. 


\section{EVA J. RODRÍGUEZ ROMERO}

mentalmente en La Habana, París y Madrid ${ }^{85}$. En la capital caribeña estuvo al frente del Jardín Botánico desde 1823 a 1835. Allí fundó los Anales de Ciencias, Agricultura, Comercio y Artes donde se publicarían todos los adelantos modernos en los diversos ramos que abarcaban. Asimismo, inspiró la creación de una Institución Agrónoma en La Habana, donde se experimentarían cultivos y prácticas agrarias diversas, así como se instruiría a los jóvenes en el régimen económico de las fincas. Además de un excelente naturalista, fue un humanista que creía en el alcance filosófico de la ciencia y su obra escrita fue abundantísima. Destacan su Historia física, política y natural de la isla de Cuba (1831, reeditada varias veces, también en francés), sus Memorias de la Institución Agrónoma de la Habana (1834), los Cinco meses en Estados Unidos de América del Norte: desde el 20 de abril al 23 de septiembre de 1836 (1836) y la Memoria sobre los objetos estudiados en la Exposición Universal de Londres y fuera de ella, bajo el punto de vista del adelanto futuro de la agricultura e industria españolas (1853).

Ya en la segunda mitad del siglo XIX, otros autores toman el relevo en materia de agricultura. Así, entre otros, José García Sanz publica su Novísima guía de labradores, jardineros y arbolistas o tratado práctico de Agricultura y Economía Rural (2 vol., Madrid, $2^{\mathrm{a}}$ ed. en 1855) y Ramón Romualdo Aguado y Mariscal escribe un Tratado del arbolista (Madrid, 1864), donde dice echar en falta personal adecuado como capataces, intermediario entre los directores y operarios para dirigir la repoblación del arbolado en bosques, jardines y arboledas ${ }^{86}$. Efectivamente, aunque había varias escuelas de agricultura y jardinería ${ }^{87}$, estas enseñanzas, así como las de la

85 Sobre la biografía, bibliografía y análisis de la obra de este naturalista $c f r$. VV.AA. (1992), $R a-$ món de la Sagra y Cuba. Actas del congreso celebrado en París, enero de 1992. 2 vol. Ed. do Castro, Sada (La Coruña).

86 AguAdo y MARISCAL, R. (1864), Tratado del arbolista, Madrid, p. 13.

87 Tradicionalmente, en España no existía una enseñanza académica, por así llamarla, específica de jardinería, sino que la formación de jardineros era fundamentalmente práctica, carente de cualquier base teórica. Los jóvenes jardineros, habitualmente hijos de consagrados jardineros, entraban en contacto con la disciplina a través del continuado trabajo como aprendices en los jardines más importantes, tanto particulares, como reales, estatales o municipales. Se trataba, pues, de un aprendizaje puramente artesanal. En el siglo XVIII, algunos de los jardineros que habían venido a España con los Borbones intentaron crear escuelas de jardinería y agricultura. El intento más serio de organizar unos estudios sólidos sobre la arquitectura y la práctica del jardín debió esperar hasta 1847, cuando Narciso Pascual y Colomer funda la Escuela Normal de Jardineros Horticultores en el Campo del Moro. Hasta 1855 no aparece la Escuela Central de Agricultura en Aranjuez. Como vemos, estas iniciativas estaban relacionadas con la Corona, hasta que se funda el Instituto Municipal de Artesanos en el Parque de Madrid en 1885. Ver sobre este tema ARIZA, C. (1986 b), «La creación de escuelas de jardinería durante los siglos XVIII y XIX», Reales Sitios, 89, 29-36.

Al contrario que en otros países, en España no se consideraba la jardinería como un arte independiente, con lo cual no fue incluida dentro de las disciplinas que se impartían en la Real Academia de Bellas Artes de San Fernando, aunque muchas veces los alumnos de arquitectura tuviesen que resolver ejercicios más o menos directamente relacionados con jardines. Del mismo modo, tampoco se olvidó 


\section{LA TEORÍA Y LA TRATADÍSTICA DEL JARDÍN EN ESPAÑA DURANTE EL SIGLO XIX}

arboricultura y la floricultura no estaban precisamente demasiado extendidas en España. Tampoco se prestaban demasiados auxilios a los agricultores, hecho que denunciará pocos años más tarde Ángel Fernández de los Ríos, cuando propone crear una Escuela práctica de Agricultura, Horticultura y Ganadería en la Casa de Campo de Madrid, cerca de la zona del Batán:

\footnotetext{
La instrucción agrícola está en la infancia en España; el labrador carece no sólo de toda noción científica de la ocupación á que se dedica, sino de los medios de mejorar sus frutos y sus ganados, porque, sobre desconocer completamente todos los progresos modernos, no tiene á su alcance, ni las especies perfeccionadas, ni los medios de comparación para apreciar los que mejor convenga á sus propiedades. Todo progreso en la agricultura, toda máquina nueva, todo adelanto en la ganadería, toda pareja de animales vivos, todo ensayo, en fin, requiere gastos, imposibles para la modesta fortuna de nuestros ya agobiados labradores. Eso que le falta al labriego es lo que debe encontrar reunido en la granja-modelo que proponemos...88
}

La última obra de agricultura aplicada a la jardinería en el siglo XIX de la cual tenemos noticia es la Novísima guía del hortelano, jardinero y arbolista (Imprenta del Colegio Nacional de Sordomudos y Ciegos, Madrid, 1885) de Balbino Cortés y Morales. En este libro se especifican los diversos trabajos de horticultura y jardinería que se deben realizar cada mes, incluye un diccionario de los términos de botánica y jardinería más usuales, todo tipo de nociones prácticas de horticultura y jardinería, así como capítulos dedicados al cultivo de árboles frutales, labores de la huerta y cultivo de plantas ornamentales.

Aparte de todos estos manuales de jardinería y de agricultura que hemos comentado, se publicaron durante todo el siglo XIX importantísimas obras de botánica. Conviene mencionar la relevancia de la tarea del Real Jardín Botánico de Madrid en pro de los avances tanto en botánica, como en agricultura y jardinería. Desde su fundación en el siglo XVIII, este establecimiento siempre había impulsado e impartido lecciones de estos conocimientos, toda vez que había coordinado la importación y aclimatación en España de especies vegetales, tanto útiles como ornamentales, en-

\footnotetext{
totalmente la jardinería en las enseñanzas de la nueva Escuela de Arquitectura, fundada en 1844, aunque no tuvo categoría de asignatura hasta el plan de estudios de 1957. Cfr. RODRíGUEZ ROMERO, E. y PRIETO, J. M. (1997), «Haciendo el jardín de las delicias. Ficción y realidad en relación a los ámbitos de recreo público decimonónicos», Archivo Español de Arte, 280, 397-418; y (1998), “'Caprichos' para un jardín de las delicias. Ficción y realidad en la escenografía de los ámbitos de recreo público decimonónicos», Archivo Español de Arte, 284, 391-406. En estos artículos se realiza un estudio comparado entre algunos proyectos fines de carrera de la Academia y ejemplos reales de jardines, paseos y plazas en el tercio central del siglo XIX. Asimismo se abordan algunas cuestiones sobre la enseñanza de la jardinería en relación a la enseñanza de la arquitectura.

88 FERNÁNDEZ DE LOS Ríos, A. (1868), El futuro Madrid, Los Libros de la Frontera, Barcelona, 1975, p. 171.
} 
viando expediciones por todo el mundo y organizando una red de corresponsalías con los jardines botánicos más importantes. Desde mediados del siglo XVIII y a principios del siglo XIX, se produce, por tanto, un auge de la botánica en nuestro país. Este interés se traduce en una labor cuyo objetivo no va a ser sólo el conocimiento científico, sino también un fin utilitario. Este será el objeto prioritario de los botánicos de la época, que intentarán conocer, propagar y perfeccionar el cultivo de aquellas plantas más útiles y usuales en la economía, medicina y artes, con preferencia de las exóticas ${ }^{89}$.

Las incansables actividades llevadas a cabo en el Real Jardín Botánico no siempre vieron la luz en las correspondientes publicaciones que cabía esperar, como explica José Luis Peset ${ }^{90}$. Pero con el siglo XIX comienzan los albores de la historia de la ciencia y algunos botánicos desempeñarán también importantes papeles como teóricos. Así, en 1800, Cavanilles publica un escrito de gran interés: Materiales para la historia de la Botánica ${ }^{91}$. Un año después será nombrado director del Jardín Botánico de Madrid. También desde 1801 Lagasca escribe obras sobre las plantas cultivadas en el Real Jardín y en los años veinte difundirá las actividades botánicas y agronómicas españolas en Inglaterra ${ }^{92}$.

Más avanzado el siglo, nos encontramos una figura de gran importancia para la historia de la botánica española, Miguel Colmeiro, al que ya hemos visto como autor de un manual de jardinería. Su primera publicación en esta línea fue el Ensayo histórico sobre los progresos de la Botánica desde sus orígenes hasta el día, con especial relación a España (1842), al que seguirá el libro La Botánica y los botánicos de la Península Hispano-Lusitana ${ }^{93}$. Se trata de una bibliografía exhaustiva de la materia, en la que se recogen novecientos treinta y dos títulos, españoles casi todos y algunos portugueses, incluyendo los autores griegos y latinos, las obras destinadas al estudio de las plantas mencionadas en la Biblia, obras árabes traducidas, obras didácticas sobre diversos ramos de la botánica desde el siglo XVI al XIX, obras descriptivas de plantas exóticas, de plantas de la Península e islas, de plantas cultivadas en jardines públicos y también colecciones académicas y periódicas. Igualmente dedica varios libros a la trayectoria del jardín Botánico del Prado, como son El Jardín Botánico de

${ }^{89}$ CAMPO, I. del (1993), Introducción de plantas americanas en España, Ministerio de agricultura, Madrid, p. 11.

90 PESET, J. L. (1995), «La botánica en las expediciones científicas españolas», Asclepio, XLVII-2, $11-25$.

91 Ibidem, p. 17.

92 LAGASCA, M. (1826), «Sketches of the Botanical, Horticultural, Agronomical and Rural Circunstances of Spain», en The Garden Magazine, 1, 236-249. 66-76.

- (1827), «On the Gardening and Botany of Spain», The Garden Magazine, 2, 393-399 y 4, 1828,

93 Colmeiro, M. (1858), La Botánica y los botánicos de la Península Hispano-Lusitana. Imp. de M. Rivadeneyra, Madrid. 


\section{LA TEORÍA Y LA TRATADÍSTICA DEL JARDÍN EN ESPAÑA DURANTE EL SIGLO XIX}

Madrid y el Gabinete de Historia Natural (1867), Importancia científica del jardín Botánico de Madrid (1869) y Bosquejo histórico-estadístico del Jardín Botánico de Madrid (1885), al cual también sitúa dentro del panorama internacional en su estudio sobre Jardines botánicos, su número, organización e importancia en las naciones más cultas e ilustradas (1894). También quiso dar a conocer la ingente labor que se había desarrollado desde el siglo anterior, estudiando y publicando materiales procedentes de las expediciones en obras como Diccionario de los diversos nombres vulgares de muchas plantas normales y notables del Antiguo y Nuevo Mundo (1871) y Primeras noticias acerca de la vegetación americana. Con un resumen de las expediciones botánicas de los españoles (1892).

No sólo en los establecimientos científicos se intentaban aclimatar las especies exóticas, sino que incluso antes de la fundación del Jardín Botánico de Madrid, ya se estaban realizando dichas experiencias en algunos Sitios Reales. De hecho, la aparición de los jardines botánicos en España se debió a iniciativas reales, al igual que había sucedido en otras naciones. Los monarcas ilustrados gustaron de reunir todo tipo de materias útiles o raras e impulsar con ello la ciencia, el comercio, la agricultura y la industria. Recordemos, por ejemplo, que el Jardin des plantes de París y el Kew Garden de Londres compartían la doble misión de ser instituciones docentes e investigadoras en el campo de la botánica y jardines para el solaz real.

En España ya existía esta tradición del interés por las plantas, en especial las medicinales, desde el Renacimiento (en tiempos de Felipe II se implantó en Aranjuez el primer jardín botánico español), pero sería con Felipe $\mathrm{V}$ cuando comienza el cultivo de plantas exóticas y útiles en los jardines, viveros y huertas de Aranjuez, que continuará durante el reinado de Fernando VI, y verá su mayor auge con Carlos III y Carlos IV. Desde 1720 se enviaban semillas extranjeras a los viveros de Aranjuez y desde 1746 se aclimataban plantas vivas ${ }^{94}$. Carlos III fundó allí también una escuela de agronomía. La época de mayor actividad de introducción de nuevas especies coincide con la creación del Jardín del Príncipe, gracias a la dedicación e interés de Pablo Boutelou que se ocupa de la adquisición para España de nuevos árboles. A Aranjuez llegaban las plantas de América y Asia desde donde se propagaban al resto de España e incluso al extranjero. A principios del siglo XIX se continuó trabajando con empeño con las plantas agrícolas, pero la invasión francesa detuvo estas experiencias que se plasmaron en el Catálogo de los árboles y arbustos del Jardín del Príncipe en el Real Sitio de Aranjuez, que escribió Pablo Boutelou en 1787, apareciendo en uno de los prólogos de la obra de Ponz, testimonio de radical importancia para el estudio de la aclimatación en España. Años más tarde, su hijo Esteban publicará una historia de los

94 Cfr. PUERTO SARMIENTO, F. J. (1988), La ilusión quebrada. Botánica, sanidad y política científica en la España Ilustrada. Serbal, C.S.I.C., Madrid, pp. 254-259. 
viveros de Aranjuez ${ }^{95}$. De cualquier forma, no abundaron tanto como debieran las publicaciones de los resultados obtenidos, el gran esfuerzo económico y organizativo en las expediciones botánicas perdió lustre por no acometer el siguiente paso, mostrar al mundo las riquezas naturales de nuestras posesiones ultramarinas ${ }^{96}$.

En el reinado de Isabel II se retoma el interés por promover la agricultura y se impulsan nuevas empresas, como la ingente labor que desempeñó Ramón de la Sagra en Cuba. En 1840, aprovechando el viaje de este personaje por diversos países europeos, el tutor de la reina le encarga adquirir semillas, árboles, arbustos, flores, verduras y legumbres que fuesen desconocidos en España para los bosques y jardines del Real Patrimonio, y también animales domésticos que por su tamaño, hermosura y demás «fuese conveniente propagar en beneficio del pais» ${ }^{97}$. El naturalista encargó diversos árboles y arbustos, «útiles para vergeles y huertos» pero no como «árboles de construcción» ${ }^{98}$, en viveros de Francia, Bélgica, Holanda y Alemania, así como colecciones de semillas, tubérculos y bulbos de trescientas especies de plantas de adorno, hortalizas, plantas tintóreas, pastas, etc ${ }^{99}$. También realizó averiguaciones acerca de los cruces entre diferentes razas en caballos, vacas, cabras y cerdos.

Entre las obras que se quedaron en el tintero, respecto a las especies vegetales que se consiguieron aclimatar en España, hubiese jugado un papel fundamental la que se habría llamado Flora Real, para cuya publicación se nombró una comisión en 1847 con miembros de la Dirección general de jardines de Palacio y Sitios Reales, de la Inspección de bosques, del Jardín Botánico y del Museo de Ciencias Naturales ${ }^{100}$. Se pretendía realizar una obra botánica con todas las especies y variedades de flores,

95 Boutelou, E. (1806), «Historia de los viveros de Aranjuez», Semanario de Agricultura y Artes, $19,209-213$ y $234-239$.

96 RoDRíGUEZ NOZAL, R. (1995), «La Oficina Botánica (1788-1835): una institución dedicada al éstudio de la Flora americana», Asclepio, XLVII-2, 169-183, p. 169.

97 SAGRA, R. de la (1841), Investigaciones para enriquecer las fincas del Real Patrimonio con nuevos plantíos, arbolados y razas útiles de animales domésticos hachas en el extrangero (sic) por don..., Madrid, Imp. del Colegio de Sordomudos, p. 3.

98 Como pinos, cedros, enebros, robles, magnolias, sauces y moreras. Recomienda que se encarguen también otras especies útiles de Estados Unidos. Ibidem, pp. 4-6.

${ }^{99}$ Sobre las plantas que llegaron a España con motivo de este encargo, y de otros encomendados también a Ramón de la Sagra, se conserva abundante documentación en el A.G.P., sec. admva., leg. 335, Estado de las plantaciones.

100 Esta comisión la integraban Pascual Asensio, director del Jardín Botánico; José Quintanilla, profesor de botánica; Lucas Fornos, catedrático de zoología del Museo de Ciencias Naturales; Fernando Boutelou, director general de Jardines; Esteban Boutelou, inspector de bosques y plantíos de Aranjuez; José Francisco Aviguivel; Agustín Pascual, ingeniero de Montes y León Mateo de la Sociedad Económica Matritense. (A.G.P., sec. admva., $c^{a} 11.793$, exp. 2: estadística, plantíos, viveros y mejoras en los Reales Sitios del Retiro, Casino, Casa de Campo, Florida, Vista Alegre, Pardo, Aranjuez, San Fernando, San Ildefonso y San Lorenzo; y nombramiento de la comisión de varios sujetos para la publicación de la Flora Real. Retiro, 9 de marzo de 1847). 
arbustos y árboles que se cultivaban en los jardines y estufas de los Reales Sitios. Para ello, desde 1846, se había pedido al jardinero mayor de cada Sitio el confeccionar una lista con todas las clases y especies vegetales, tanto indígenas como exóticas, indicando el número y el nombre vulgar y botánico de cada una ${ }^{101}$. A la vista de los listados recibidos, Fernando Boutelou, que era el director general de Jardines y Bosques Reales, expresó su satisfacción al comprobar que se poseían «...casi todas las especies y variedades de árboles de mérito... que se conocen y cultivan en Europa, con la ventaja de tener aclimatadas al aire libre y con mayor frondosidad que en ninguna otra parte, muchos vegetales que en el extrangero (sic) tienen necesidad de resguardarse en estufas é invernáculos» ${ }^{102}$ Sobre todo en árboles frutales la supremacía de España era clara. Sin embargo, reconoció que en el cultivo de «plantas delicadas y de adorno» sí se sufría retraso respecto al extranjero, no por falta de conocimientos en la materia, sino por falta de medios, ya que ninguna estufa de las de los Sitios Reales estaba construida según los «medios modernos y las necesidades de la época». Aprovecha la ocasión, por tanto, para sugerir la necesidad que había de construir algún buen invernadero (según los planos que consiguió en su viaje por Francia, Bélgica e Inglaterra de los mejores invernáculos de aquellos países) y también de avivar el trasiego de personal para recoger simientes en establecimientos de horticultura de todo el mundo, ya que en los Sitios Reales no hay «un sistema periódico de renovación» de semillas.

Como base de la publicación de la Flora Real, se mandó hacer más adelante un listado por orden alfabético de todas las especies vegetales, indicando en tres columnas las siguientes características de las plantas: si es medicinal, venenosa, económica o de adorno; si es anual o bianual; y si es perenne o de fruto ${ }^{103}$. Lamentablemente, la realización de esta obra se quedó en la mera recopilación de datos y su organización, como había sucedido en otras ocasiones.

Esțe es el panorama que, a nivel teórico, presentaba la jardinería en España durante el siglo XIX. En la producción propia predominaban, pues, los tratados prácticos de índole agrícola o botánica aplicados a la jardinería sobre las obras de teoría del jardín propiamente dichas. Además, estas últimas eran deudoras de los tratados y libros de imágenes que nos llegaban desde el extranjero, que eran los que se manejaban preferentemente en los diversos y variopintos centros de enseñanza en los que se impartían conocimientos sobre jardinería. En la práctica se refleja, más o menos, la misma situación. Por un lado, predominan los jardineros de otros países que eran

101 Ibidem. Se conservan también los registros de entrada de las listas desde cada Real Sitio, pero no éstas, ya que, el 16 de noviembre de 1846, Fernando Boutelou remite todos los listados al Intendente general de la Real Casa. Desgraciadamente, no hemos conseguido localizarlas.

102 Ibidem. Carta de Fernando Boutelou, dirigida al Intendente general, que acompañaba a los listados de especies.

103 Ibidem. 
llamados por la Corona o la nobleza para trabajar en sus jardines; por otro lado, no existe una profesión específica de arquitecto-paisajista, como podía suceder en Inglaterra, Francia o Italia, sino que aquí el diseño de jardines podía estar en manos de meros jardineros prácticos o, si no, de arquitectos que intervenían tanto en los edificios como en los parques. 